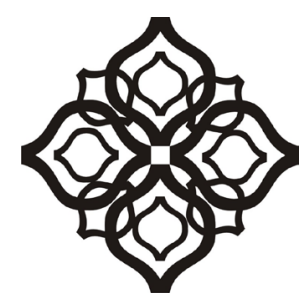

Shirkah

Journal of Economics and Business 


\section{Shirkah}

Journal of Economics and Business

Vol. 2, No. 2, May-August 2017

ISSN: 2503-4235 (p); 2503-4243 (e)

\section{Editor in Chief}

Sri Walyoto

\section{Editorial Boards}

Abu Umar Faruq Ahmad, UBD School of Business and Economics, Brunei Darussalam

Amelia Fauzia,

Asia Research Institute, National University of Singapore, Singapore

Cedomir Nestorovic,

ESSEC Business School Asia Pacific, Singapore

Dwi Condro Triono,

Faculty of Islamic Economics and Business, IAIN Surakarta, Indonesia

Fahmy Radhi,

Faculty of Economics and Business Universitas Gadjah Mada, Yogyakarta,

Indonesia

Hasan Basri,

Syiah Kuala University, Aceh, Indonesia

Johan Fischer,

Department of Social Sciences and Business Roskilde University, Denmark

Masudul Alam Choudhury,

Postgraduate Program in Islamic Economics and Finance, Trisakti University,

Jakarta, Indonesia and the College of Economics and Political Science (CEPS) in

Sultan Qaboos University (SQU), Oman

M. Falik Isbah,

School of Humanities and Social Science, University of New South Wales, Australia M. Ishaq Bhatti,

La Trobe Business School Department of Economics and Finance La Trobe

University, Australia

Najib Kailani,

Pascasarjana, Universitas Islam Negeri (UIN) Sunan Kalijaga, Yogyakarta, Indonesia 
Nunung Nurul Hidayah,

Aston Business School, Aston University, Birmingham, United Kingdom

Shaikh M Ghazanfar,

Departement of Economics, University of Idaho, Russian Federation

\section{Managing Editors}

Fitri Wulandari

Jasanta Perangin-angin

\section{Assistant to Editor}

M. Endy Saputro

M. Zainal Anwar

Supriyanto

Shirkah Journal of Economics and Business is a peer-reviewed journal published three times a year (January-April, May-August and September-December) by Faculty of Islamic Economics and Business, Institut Agama Islam Negeri (IAIN/ State Institute for Islamic Studies) Surakarta Central Java, Indonesia. The main objective of Shirkah is to offer an academic space of exchange ideas and initiate the increase number of qualified article produced by postgraduate students, practitioners and academicians.

\section{Editorial Office}

Ruang Jurnal Shirkah

Ground Floor, West Gate,

Faculty of Islamic Economics and Business

IAIN Surakarta

Jln. Pandawa No. 1, Kartasura, Sukoharjo, Jawa Tengah Kode Pos. 57168

Phone (+62271) 781516 Fax: (+62271)782336

E-mail: shirkahiainsurakarta@gmail.com

Website: http://shirkah.or.id/ 


\section{Shirkah}

Journal of Economics and Business

Vol. 2, No. 2, May-August 2017

ISSN: 2503-4235 (p); 2503-4243 (e)

\section{Table of Contents}

\section{Articles}

Shairil Izwan Taasim

Ramali Yusoff

An Instrument Developing Cashless in Malaysia

Aam S. Rusydiana

Irman Firmansyah

Efficiency versus Maqasid Sharia Index An Application on Indonesia

Islamic Bank

Azhar Ibrahim

The Call for Islamic Economics Shades of Contestation

Warsono

Deferred Tax Assets and Deferred Tax Expense Against Tax Planning Profit Management

Lisdawati Arifin

Earning on Response Coefficient in Automobile and Go Public

Companies

Farihatul Qamariyah

Waroeng Steak: Spritual Company in the Context of Post-Capitalism 


\title{
Earning on Response Coefficient in Automobile and Go Public Companies
}

\author{
Lisdawati Arifin \\ Universitas Bungkarno \\ lisdawati_arifin@yahoo.com
}

\begin{abstract}
This study aims to analyze factors that influence earnings response coefficients (ERC), simultaneously and partially, composed of leverage, the systematic risk (beta), growth opportunities (market to book value ratio), and the size of the firm (firm size), selection of the sample in this study the author take 12 automakers and components that meet the criteria of completeness of the data from the year 2008 to 2012, entirely based on consideration of the following criteria: (1) the company's automotive and components are listed on the stock exchange, (2) have the financial statements years 2008-2012 (3) has a return data (closing price) the first day after the date of issuance of the financial statements. This study uses secondary data applying multiple linear regression models to analyze and test the effect of independent variables on the dependent variable partially (t-test), simultaneous (f-test), and the goodness of fit (R-square) on a research model. The result shows that leverage, beta, growth opportunities (market to book value ratio) and size along with (simultaneously) the effect on the dependent variable (dependent variable) earnings response coefficients. Partially leverage negatively affect earnings response coefficients, partially beta negatively correlated earnings response coefficients, partially growth opportunities (market to book value ratio) significant effect on earnings response coefficients, partially sized companies (firm size) significantly influence earnings response coefficients
\end{abstract}

Keywords: earnings response coefficients, leverage, systematic risk (beta) Growth opportunities, size of the company 


\section{Introduction}

Statement of financial accounting standards (IAS) 1 states profit has benefits for assessing management performance, helping to estimate representative earnings capacity in the long terms, it forecast earnings and assess risks in investments or loans (FASB, 1985; Fainshmidt, 2017). One of the elements in the financial statements of the most widely observed and awaited information is an income statement, a report that provides information on profits (earnings) achieved by the company during the period (Vakharia, 2017). Profit achieved by a company is one measure of the performance and consideration by investors or creditors in making investment decisions or to provide additional credit, firms reporting high profits will certainly encouraging investors to invest because they will get paid on the each shareholding owned (Gianni 2017; Brown, 2017; Berchicci, 2017). Earnings information is a reference for investors to invest to the company for earnings, positive or negative, obtained from the company's income statement will affect stock returns. The magnitude of this effect will be low, especially for a negative earnings (loss). Generally in knowing good earnings quality can be measured using earnings response coefficient (ERC), which is a form of measurement in the information content of profit. Definition of earnings response coefficients (earnings response coefficient) is defined as the effect of each dollar of unexpected earnings on stock returns, and is usually measured by the coefficient of the regression slopa abnormal stock returns and unexpected earnings.

More specific research examining the ERC performed by Andayani (2007) on the factors that affect earnings response coefficient in companies listed in Jakarta Stock Exchange. By using some of the factors that is always associated with the ERC on previous research, the study tried to find out the relationship or influence the persistence of earnings, capital structure, beta or risk, growth opportunities and the size of the company with earnings 
response coefficient. With such thinking that the more permanent income changes over time, the higher the profit coefficient because this condition indicates that the profits from the company is continuously increasing, apart from that relation to the capital structure.

Other research on the factors that influence the ERC conducted by A. Zubaidi Indra Agus Zahron, Ana Rosianawati (2008). Of the four factors that can affect the quality of earnings is only beta and market to book value ratio has a significant influence on the risk of earnings quality, while other variables, namely leverage and size did not significantly affect the quality of earnings, but empirically, a significant difference between levarage independent variables, beta, market-book value ratio, as well as firm size together against ERC on the property and real estate company listed on the Indonesia Stock Exchange in 2004-2008.

Based on the above background, the authors are keen to re-analyze the factors associated with the ERC. In a previous study tested several variables that provide different results. Assuming context, research time and the object or the sample under study is different, so the research can yield different conclusions. The factors used in this study is the leverage, proxied systematic risk in the market beta, opportunity grow proxied by the market to book value ratio, and the size of the company (firm size). The formulation of research problems are is leverage, beta, growth opportunities, and firm size earnings response coefficient effect on either partially or simultaneously? The purpose of this study was to test is there a leverage effect, beta, growth opportunities, and firm size of the earnings response coefficient either partially or simultaneously, against earnings response coefficient (ERC).

Signaling theory in this study explained that the management of the company as a party that gives a signal which contains information on income in the financial statements. Signal theory states that the company 
is of good quality would deliberately give a signal to the market in the form of information, so the market is expected to differentiate good and bad quality. If the earnings announcement as a signal of good (good news) for investors, the rise in corporate profits, then the reaction brought to the stock price is rising stock prices, and vice versa.

\section{Financial Statements and Annual Report}

Definition of Financial Statements in accordance with Financial Accounting Standards (GAAP) in the convergence to IFRS as issued by the Institute of Accountants Indonesia (IAI), namely: "Financial Reports section of the financial reporting process. Complete financial statement normally includes: statements of financial position, income comprehensive statement, changes in the position of the financial presented in different ways (such as a cash flow statement or fund flows), notes and other reports an explanatory material that are an integral part of these financial statements. Besides including the schedule and additional information related to the report, for example, the financial information industry and geographical segments and the disclosure of the effect of price." It has been supported the argument that the annual report and the financial statements (financial report) as a primary means of delivering information by management to parties outside the company (Lin, 2017; Detthamrong, 2017). The annual report aims to communicate the financial condition and other information to shareholders, creditors and other stakeholders. The financial statements are an important tool for investors to know the progress of the company periodically. The sooner investors published financial reports are audited financial statement or the financial anaudited statment, the more useful for investors (Abdin, 2017; Papadamou, 2017; Vo, 2017). 


\section{Earnings Response Coefficient (ERC)}

Earnings quality may be indicated as the ability to gain information provide a respons to the market. In other words, earnings reported have a response force (power of response). The strong market reaction to earnings information reflected by the earnings response coefficients (ERC) shows the quality of reported earnings. Scott (2000) and Etty (2008) states that the Earnings Response Coefficient (ERC) measures how much stock returns in response to the profit figures reported by the companies that issue securities. In other words, earnings response coefficient (ERC) is a reaction to the earnings was announced (published) by the company. This reaction reflects the quality of a company's reported earnings. And the level of earnings response coefficient (ERC) is determined responsive power that is reflected from the information (good / bad news) contained in profits. Earnings response coefficient (ERC) is one measure or proxy is used to measure the quality of earnings (Collins et al., 1984).

Companies with high leverage level means having greater debt than capital. Thus, if an increase in the income benefit is the debtholders, because the debtors have faith that the company will be able to make payments on the debt. However, this will be responded negatively by investors because investors will assume that the company will be more profitable because more priority creditors debt repayment rather than payment of dividends. In doing so the better the condition of corporate profits, the more negative the response of shareholders. Results of tests performed by Mulyani et al. (2007) showed that financial leverage significantly affect the earnings response coefficient (ERC).

Etty (2008) states there are negative effect between coeficient Leverage Response to Earnings (ERC). Dhaliwal in line with the results of their research, Lee and Farger (1991) in Etty (2008), which prove that Leverage negatively affect earnings response coefficient that is Earnings Response Coefficient (ERC). 
$\mathbf{H 1}$ : There is a negative impact of leverage, on Earnings response coefficient

Investors will reduce the level of risk acceptance by considering the specific risk of a company in making investment decisions. Sensitivity of investors to information about the company little risk will be greater for companies with less risk more credible (Palupi, 2006). Mulyani et al. (2007) shows that the risk systematic negatively related to the ERC. In line with research by Collins and Kothari (1989) that the risk showing the variation between companies, and risk-free interest rate which shows the variation over time empirically proven significant negative effect to the earnings response coefficient. Different with the research that was done by Margaretta Jati Palupi (2003) suggest a significant difference between systematic risks (beta) to Earnings response coefficient.

H2: There is a positive influence between beta, on earnings response coefficient

Collins and Kothari (1989) argue companies that have greater growth opportunities will have higher earnings response coefficient. This condition indicates that the greater the opportunity to grow the company, the higher the chance of companies gain or increase profits from the company in the future. Another study conducted Andyani and Mulyani (2007) suggests there is significant influence between growth opportunities (market to book value ratio) against partially earnings response coefficient.

H3: The opportunity to grow significantly influence the earnings response coefficient Company size is a proxy of price informativeness. Large enterprises are considered to have more information than small enterprises. Consequently the more informative stock prices then the lesser charge current earnings information. Nevertheless Easton and Zmijewski (1989) shows the amount of the company is not a significant explanatory variable for the earnings response coefficient other. Research performed by 
Sri Mulyani, Nur Fun and Andayani (2007) reported significant effect on earnings firm size partial response coefficient.

H4: The size of the company a significant effect on earnings Coeefficient response

In his research, A. Zubaidi Indra, Agus Zahron and Ana Rosianawati (2011) empirically find a significant difference between the independent variables include the leverage factor, beta, market to book value ratio, as well as firm size against quality of earnings (earnings response coefficient) simultaneously.

H5: There is a positive influence between leverage, beta, growth oppurtunities (market to book value ratio) firm size of the coefficient simultaneously earnings response coefficient response simultaneously.

Framework

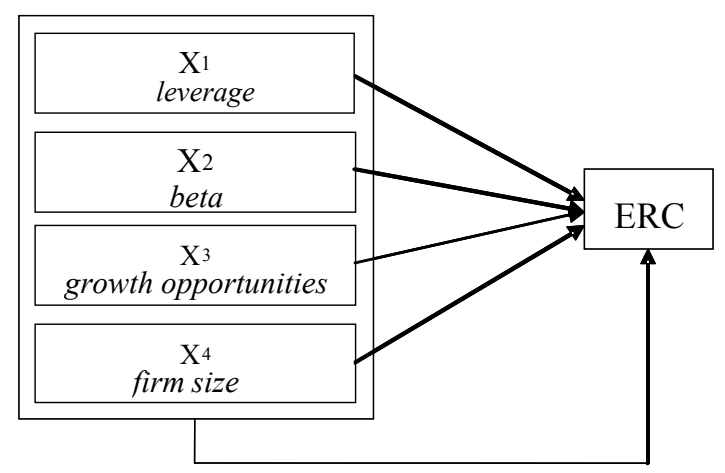

The population used in this study is a publicly traded company on the Indonesian Stock Exchange (BEI). The study period covers a period of five years. How sampling by purposive sampling or judgment in order to see the effect of the three variables and components to the automotive industry. The data used in this research is secondary data, that the financial statements were obtained from the Capital Market Reference Center Indonesia Stock Exchange. The annual financial statements issued by companies of automotive and components are listed on the Stock 
Exchange, Indonesian Capital Market directory is (ICMD), JSX Statistics, IDF Quarterly Statistics, IDX montly Statistics, Fact Book and list the Securities Exchange (EFD).

To select the sample, the author took 12 automakers and components that meet the criteria of completeness of the data from the year 2008 to 2012, entirely based on consideration of the following criteria: automotive and components companies listed on the Stock Exchange; have the financial statements for 2008-2012; and has a return data (closing price) the first day after the date of issuance of the financial statements.

Variable of Operational Research

Table 1

Variable Operationalization

\begin{tabular}{|c|c|c|c|c|}
\hline Variables & $\begin{array}{c}\text { Sub } \\
\text { Variables }\end{array}$ & Indicator & Scale & Reference \\
\hline $\begin{array}{l}\text { 1. Dependent } \\
\text { Variable (Y) }\end{array}$ & & & & \\
\hline $\begin{array}{l}\text { Earnings } \\
\text { Response } \\
\text { coefficient } \\
(\text { ERC) } \\
(\mathrm{Y}) \\
\text { CARit = } \alpha 0+ \\
\alpha 1 \mathrm{UEit}+\text { cit }\end{array}$ & CAR & $\begin{array}{l}\text { - Anormal return } \\
\text { securities i the event } \\
\text { period to } \mathrm{t} \\
\text { - Return stock i the } \\
\text { event period to } \mathrm{t} \\
\text { - Return expectations } \\
\text { securities I to the } \\
\text { event period to } \mathrm{t} \\
C A R_{, t,}[t 1-t 2]=\sum A R_{i, t=t 1}\end{array}$ & Ratio & $\begin{array}{l}\text { Brown and } \\
\text { Warner, } 1985 \\
\text { Suaryana } \\
(2004)\end{array}$ \\
\hline
\end{tabular}




\begin{tabular}{|c|c|c|c|c|}
\hline Response & UE & $\begin{array}{l}\text { - Unexpected earnings } \\
\text { company's iin the } \\
\text { period (years) } \mathrm{t} \\
\text { - Profit accounting } \\
\text { company'si in period } \\
\text { (years) } \mathrm{t} \\
\text { - Profit accounting } \\
\text { company's I in the } \\
\text { period (years) before } \\
(\mathrm{t}-1) \\
\text { - } U E_{i t}=\frac{\left(E_{i t}-E_{i t}-1\right)}{E_{i t}-1}\end{array}$ & & \\
\hline \multicolumn{5}{|l|}{$\begin{array}{l}\text { 2. Independent } \\
\text { Variables (X) }\end{array}$} \\
\hline a. leverage (X1) & $D A R$ & $\begin{array}{l}\text { - Total Amoun of debt } \\
\text { - Total aseet } \\
\text { - } L e v_{i t}=\frac{T U_{i t}}{T A_{i t}}\end{array}$ & ratio & $\begin{array}{l}\text { Dhaliwal } \\
\text { (1991) }\end{array}$ \\
\hline $\begin{array}{l}\text { b. Systematic risk } \\
\text { (beta) }(\mathrm{X} 2)\end{array}$ & Beta & $\begin{array}{l}\text { - Return firm i year I } \\
\text { - Beta is the measure } \\
\text { koefisein Ri changes } \\
\text { due to changes in } \\
\text { Rm } \\
\text { - Return market in i } \\
\text { Rit }=\alpha i \text { + } \beta \text { it RMT } \\
+ \text { Eit }\end{array}$ & Ratio & $\begin{array}{l}\text { Hartono, } \\
2003\end{array}$ \\
\hline $\begin{array}{l}\text { 3. Growth } \\
\text { Opportunities } \\
\text { (Market to book } \\
\text { value ratio) (X3) }\end{array}$ & $\begin{array}{l}\text { Market - } \\
\text { to - book } \\
\text { valueratio }\end{array}$ & $\begin{array}{l}\text { - The market value of } \\
\text { equity } \\
\text { - The book value of } \\
\text { equity } \\
\text { - The market value of } \\
\text { equity } \\
\text { - The book value of } \\
\text { equity }\end{array}$ & & Jaswad 2003 \\
\hline $\begin{array}{l}\text { 4. The size of the } \\
\text { firm (Firm Size), } \\
\text { (X4) }\end{array}$ & $\begin{array}{l}\text { Natural } \\
\text { logarithm } \\
\text { (Ln) Total } \\
\text { Activa }\end{array}$ & - Total Activa & Ratio & $\begin{array}{l}\text { Collins and } \\
\text { Kothar, } 1989\end{array}$ \\
\hline
\end{tabular}


Multiple linear regression analysis is an analysis that is used to find an association between two or more independent variables on the dependent variable. The model used in this study:

ERCit $=\beta 0+\beta 2$ LEVit $1+\beta 3$ Betait $+\beta 4$ MBit $+\beta 5$ SIZEit $+\varepsilon$ it

Information :

ERCit $=$ Coefficient company earnings response $i$ in period $\mathrm{t}$

Levit = The capital structure of the company $i$ in period $\mathrm{t}$

Betait $=$ Systematic risk (beta) companies $i$ in period $\mathrm{t}$

MBit $=$ Growth Companies $i$ in period $\mathrm{t}$

SIZEit $=$ Size Companies $i$ in period $\mathrm{t}$

Multiple linear regression

Processing of data by multiple linear regression analysis, to see the effect of leverage, beta, Market to book value ratio, Firm Size and mathematical approach as follows:

$$
\mathrm{Y}=\mathrm{a}+\mathrm{b} 1 \mathrm{x} 1+\mathrm{b} 2 \mathrm{X} 2+\mathrm{b} 3 \mathrm{X} 3+\mathrm{b} 4 \mathrm{X} 4
$$

Information :

$\mathrm{Y}=$ Earnings response coefficient

$\mathrm{a}=$ constants

$\mathrm{b} 1=$ regression coefficient leverage

$\mathrm{b} 2$ = regression coefficient beta

b3 = regression coefficient Market To book value ratio

$\mathrm{b} 4=$ The regression coefficient size

$\mathrm{X} 1$ = leverage

$\mathrm{X} 2$ = beta

$\mathrm{X} 3$ = Market to book value ratio

$\mathrm{X} 4$ = size 
Here is how to detect the symptoms of deviation from the classical assumptions above third. Multicolinearity, to test multicolinierity to see VIF $=1 /(1-r 2)$, if close to 1 means multikol harmless (Gujarati, 1995). Autocorrelation, to detect the presence of symptoms can be used autokolerasi Durbin-Watson test test. Heterocedastity, to detect heterokedastisitas can be done by Spearman rank correlation test. Statistical descriptions provide an overview or a description of the data shown in the average value (mean), standard deviation, variance, maximum and maximum and skewness (skewed distribution). The following will explain more about Leverage, Beta, Growth and Firm Size oportunities in companies' otomitif and components are listed on the Stock Exchange during the years 2008-2012.

Table 2

Descriptive Statistics Test Results

Descriptive Statistics

\begin{tabular}{|l|c|r|r|r|r|}
\hline & $\mathrm{N}$ & Minimum & Maximum & \multicolumn{1}{c|}{ mean } & $\begin{array}{c}\text { Std. } \\
\text { deviation }\end{array}$ \\
\hline ERC & 60 & -14.13 & $7: 08$ & -3.0830 & 8.82402 \\
LEVERAGE & 60 & .17 & .91 & .5218 & .19065 \\
BETA & 60 & -1.82 & 1.71 & .9444 & .42286 \\
GROWTH & 60 & .22 & $9: 04$ & 1.7138 & 1.59391 \\
SIZE & 60 & 25.65 & 32.84 & 28.4190 & 1.74607 \\
Valid N & 60 & & & & \\
(listwise) & & & & \\
\hline
\end{tabular}

From the above data, it shows that the value of $\mathrm{n}$ as the enterprise data used in the study of 60 samples. Earnings response coefficient has a minimum value of -14.13; the maximum value of 7.08 ; the average value of -3.08; and a standard deviation of 8.82. Thus the average growth in earnings response coefficient reaches only -3.08 per year. Leveragehas a minimum value of 0.17 ; The maximum value of 0.91 ; the average value 
of 0.52 ; and a standard deviation of 0.19 . This means that the average asset growth only reached $52 \%$. Beta (risk) has a minimum value of -1.82; the maximum value of 1.71 ; the average value of 0.94 ; and a standard deviation of 0.42 . Therefore, the level of systematic risk reached an average below 1, relatively low compared to the average level of risk in the Indonesia Stock Exchange. Growth opportunitieshave a minimum value of 0.22 ; the maximum value of 9.04; the average value of 1.71 ; and a standard deviation of 1.59 . Similarly, the rate of sales growth expectations for annual average only reached $1.17 \%$ at a standard deviation of $1.59 \%$ also remains relatively low throughout the study period, for the year 2008 to 2012 there was a crisis of the world, so it is very volatile.Firm sizehas a minimum value of 25.65; the maximum value of 32.84; the average value of 28.41; and a standard deviation of 1.74 . Therefore, the asset growth reached an average of $28.41 \%$ is relatively high compared to the industry average is 5 to $10 \%$ per year

From processing the data above, it can be concluded that the condition of the company's growth Automotive and Components during the study period showed growth in relatively low compared to the average growth in industrial companies. 


\section{Test Results}

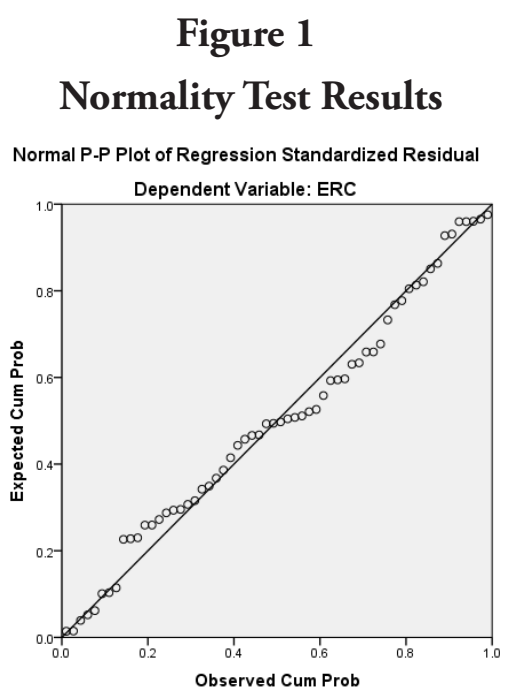

At the output of SPSS version 20.0, PP Plot of Regrassion the data dots tend to follow a straight diagonal line, then the data can be considered normally distributed or meet the assumption of normality.

\section{Table 3}

\section{Test Results Multicollinearity}

\begin{tabular}{|c|c|c|c|c|c|c|c|c|}
\hline & \multirow[t]{2}{*}{$\begin{array}{l}\text { Model } \\
\text { B }\end{array}$} & \multicolumn{2}{|c|}{$\begin{array}{c}\text { Coefficients } \\
\text { Unstandardized }\end{array}$} & \multirow[t]{2}{*}{$\begin{array}{c}\text { Standardized } \\
\text { Coefficients }\end{array}$} & \multirow[t]{2}{*}{$\mathrm{T}$} & \multirow{2}{*}{$\begin{array}{l}\text { Sig. } \\
\text { Tole- } \\
\text { rance }\end{array}$} & \multicolumn{2}{|c|}{$\begin{array}{l}\text { Collinearity } \\
\text { Statistics }\end{array}$} \\
\hline & & $\begin{array}{l}\text { Std. } \\
\text { Error }\end{array}$ & Beta & & & & VIF & \\
\hline \multirow{5}{*}{1} & (Constant & 1,763 & 4120 & & .428 & .000 & & \\
\hline & LEVERAGE & -8202 & 3502 & -1182 & -5818 & .000 & .982 & 1,018 \\
\hline & BETA & -3081 & 3,425 & -.112 & -.899 & .372 & .928 & 1,078 \\
\hline & GROWTH & 4078 & 1,834 & .232 & 2,224 & .030 & .654 & 1,528 \\
\hline & SIZE & 9447 & 3272 & .526 & 2887 & .006 & .632 & 1,582 \\
\hline
\end{tabular}

Based on the above table shows that the variable Earnings Response Coefficient (ERC), Leverage, Beta, Size Growth opportunities and VIF value is below 10 and the value of tolerance showed no independent 
variables that have a tolerance value of less than 0.1 ; thus these variables did not happen multicollinearity.

Figure 3

Test

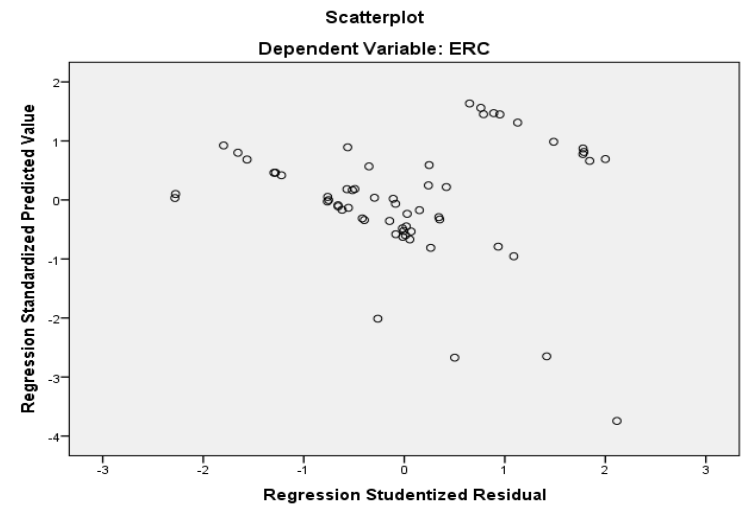

Based on the picture above it can be concluded that there is no clear pattern, and dots spread and does not form a specific pattern, it does not happen heterokedastisitas.

Table 4

Test Results Autocorrelation

Model Summary

\begin{tabular}{|l|c|r|r|r|r|}
\hline Model & \multicolumn{1}{|c|}{$\mathrm{R}$} & R Square & $\begin{array}{c}\text { Adjusted R } \\
\text { Square }\end{array}$ & $\begin{array}{c}\text { Std. Error of } \\
\text { the Estimate }\end{array}$ & Durbin-Watson \\
\hline 1 & $.712 \mathrm{a}$ & .668 & .622 & 4.30350 & 2,036 \\
\hline
\end{tabular}

a. Predictors: (Constant), GROWTH, SIZE, BETA, LEVERAGE

b. Dependent Variable: ERC

From result output table above, it can be seen that the value of Durbin-Watson resulting from the regression model is 2,036. While the table with significance $\alpha$ DW 0:05, the number of data $\mathrm{n} 60$ and $\mathrm{k}$ is 4 , the value of $1.4443 \mathrm{dL}$ and $\mathrm{dU}$ at 1.7274 . Rated $4-\mathrm{dL}$ by 2.5557 and $4-\mathrm{dU}$ value of 2.2726. It can be concluded that the value of $\mathrm{dU}<\mathrm{DW}<4$-du or 
$1.4443<2.036<2.2726$, meaning that no autocorrelation.

\section{Test Results Statistics}

Partial test $\left(\mathbf{t}_{\text {count }}\right.$ test $)$

\section{Table 5}

\section{Regression Coefficients}

\begin{tabular}{|c|r|r|r|r|r|}
\hline \multirow{4}{*}{$\begin{array}{c}\text { Model } \\
\text { B }\end{array}$} & \multicolumn{2}{|c|}{$\begin{array}{c}\text { Coefficients } \\
\text { Unstandardized }\end{array}$} & $\begin{array}{c}\text { Standardized } \\
\text { Coefficients }\end{array}$ & \multicolumn{1}{c|}{ T } & \multicolumn{1}{c|}{ Sig. } \\
\cline { 2 - 4 } & Std. Error & \multicolumn{1}{c|}{ Beta } & & & \\
\hline \multirow{4}{*}{1 (Constant) } & 1,763 & 4120 & & .428 & .000 \\
LEVERAGE & -8202 & 3502 & -1182 & -5818 & .000 \\
BETA & -3081 & 3,425 & -.112 & -.899 & .372 \\
GROWTH & 4078 & 1,834 & .232 & 2,224 & .030 \\
& 9447 & 3272 & .526 & 2887 & .006 \\
\hline
\end{tabular}

a. Dependent Variable: ERC

Partial test results (test of $\mathrm{t}$-count) for each variable, as follows: first, the results of the partial testing of the effect of Leverage Earnings Response Coefficient (ERC) show $\mathrm{t}$ significance of 0,000 smaller than the 0.05 level, so statistically significantly influence Leverage to Earnings Response Coefficient (ERC), the coefficient is negative it means between Leverage and Earnings Response Coefficient (ERC) associated negative, it shows that if leverage increases, Earnings Response Coefficient (ERC) decreased. Second, Beta influence on the test results of the Earnings Response Coefficient (ERC) showed significant t 0.372 greater than the 0.05 level, so statistically partially Beta has no effect on Earnings Response Coefficient (ERC). Third, partial test results Growth opportunities to Earnings Response Coefficient (ERC) 0,030 t show significantly smaller than the significant level of 0.05, so statistically growth opportunities significantly affect Earnings Response Coefficient (ERC), Marked positive coefficient means betweengrowth opportunitiesand Earnings Response Coefficient (ERC) positively related, 
suggesting that if growth opportunities increases, Earnings Response Coefficient (ERC) also increased.

Fourth, size of the partial test results Earnings Response Coefficient (ERC) showed significant t 0,006 smaller than the 0.05 level, so statistically significant effect partially size with Earnings Response Coefficient (ERC), The coefficient is positive, it means between the size andEarnings Response Coefficient (ERC) positively related, suggesting that if the Size increases, Earnings Response Coefficient (ERC) also increased. Based on the above table, the model of multiple linear regression equation was obtained:

$$
Y=1,763-8,202 X 1-3,081 X 2+4,078 X 3+9,447 X 4
$$

From the results of the multiple linear regression equation, each independent variable can be interpreted influence on Earnings Response Coefficient (ERC). If leverage (X1), Beta (X2), Growth opportunities (X3) and Size (X4) is equal to zero, then the value Earnings Response Coefficient (ERC) (Y) of 1,763. Any increase leverage (X1) of 1 percent and other independent variables constant, Earnings Response Coefficient (ERC) decreased by $8.20 \%$. Earnings Response Coefficient (ERC) decreases. Each increase of 1 unit Beta and other independent variables constant, Earnings Response Coefficient (ERC) decreased by 3,081 percent. The coefficient is negative means going negative relation between the DAR with abnormal stock returns, increasing beta (risk), and Earnings Response Coefficient (ERC) drop. Any increase in Growth opportunities a 1 percent and other independent variables constant, the abnormal stock returns increased by 4.078 percent. The coefficient is positive, meaning a positive relationship between opportunities to grow with Earnings Response Coefficient (ERC), Getting up growth opportunities, then Earnings Response Coefficient (ERC) more increasing. Size each increase of 1 percent and other independent 
variables constant, Earnings Response Coefficient (ERC) an increase of 9.47 percent. The coefficient is positive, meaning a positive relationship between the Size and Earnings Response Coefficient (ERC), Getting up Size, Earnings Response Coefficient (ERC).

Simultaneous Test $\left(\mathrm{F}_{\text {count }}\right.$ test $)$

\section{Table 6 \\ ANOVA Variant Analysis \\ ANOVA ${ }^{\mathrm{a}}$}

\begin{tabular}{|rl|r|r|r|c|l|}
\hline Model & & Sum of Squares & Df & mean Square & F & Sig. \\
\hline \multirow{4}{*}{1} & Regression & 1049.842 & 4 & 262461 & 4,172 & $.000 \mathrm{~b}$ \\
& Residual & 1018.605 & 55 & 18520 & & \\
& Total & 2068.448 & 59 & & & \\
\hline
\end{tabular}

a. Dependent Variable: ERC

b. Predictors: (Constant), GROWTH, SIZE, BETA, LEVERAGE

Based on table 6 above, using a 95\% confidence level, $a=0.05$, df 1 (the number of variable -1$)=4$, df $2(n-k-1)=55(60-4-1)$, the obtained results $\mathrm{F}$ study of 4,172 . Values obtained $0,000^{\mathrm{b}}$ significance. This value is smaller than level of $\alpha 0.05$. Thereby simultaneously from Leverage, Beta, Growth opportunities and Size significant effect on Earnings Response Coefficient (ERC). Rated R square (R2) or the coefficient of determination is used to measure the ability of the model to explain variations in the dependent variable. R2 value is between zero and one. The R2 little ability of independent variables in explaining the dependent variable is very limited. A value close to one significant independent variable provides all the information needed to predict variations in the dependent variable. Results of testing the hypothesis terminated can be seen in Table 4.6 below. 


\section{Table 7}

\section{The value of R Square Hypothesis \\ Model Summary}

\begin{tabular}{|l|r|r|r|r|}
\hline Model & R & R Square & \multicolumn{1}{|c|}{$\begin{array}{c}\text { Adjusted R } \\
\text { Square }\end{array}$} & $\begin{array}{c}\text { Std. Error of the } \\
\text { Estimate }\end{array}$ \\
\hline 1 & $.712 \mathrm{a}$ & .668 & .622 & 4.30350 \\
\hline
\end{tabular}

a. Predictors: (Constant), GROTWH, SIZE, BETA, LEVERAGE

From the results of hypothesis testing known to the $\mathrm{R}$ value of 0.712 (close to one) means there is a very strong relationship between Leverage, Beta, Growth opportunities and Firm Size to Earnings Response Coefficient (ERC), Adjusted R Square of 0.622, means that the direct influence of independent variables on the dependent variable amounted to $62.2 \%$, while $37.8 \%$ are influenced by other factors outside the model which is not included in this study were categorized as an error. Standard Error of the Estimate determines the number of errors in a regression model to predict the value of Y. From the regression results obtained value of 4.3035 (unit Earnings Response Coefficient), It means the number of errors in mempediksi Earnings Response Coefficient (ERC) at 4.3035.

Hypothesis one $(\mathrm{H} 1)$ to determine the effect of independent variables (independent vaiable) Leverage partially on the dependent variable (dependent vaiable) Earnings Response Coefficient (ERC). Table distributiont at a $=0.5$, the degrees of freedom (df) 60-4-1 = 55, with a twosided test (significance 0.05 ) was obtained t table of 2.004, based on table $4.5, \mathrm{t}$ research by $5.818 \mathrm{t}$ count $>\mathrm{t}$ table $(5818>2,004)$, then accept and reject $\mathrm{Ho} \mathrm{Ha}$, meaning partially significant effect between leverage against Earnings Response Coefficient (ERC); because the coefficient is negative, then the negative effect on Earnings Leverage Response Coefficient (ERC).

Hypothesis two (H2) determine the effect of the independent variable (independent variable) Beta partially on the dependent variable 
(dependent variable) Earnings Response Coefficient (ERC). Distribution table $t$ at $\mathrm{a}=0.5$, the degrees of freedom (df) 60-4-1 = 55, with a twosided test (significance 0.05 ) was obtained $t$ table of 2.004 , based on table 4.5 , $\mathrm{t}$ research at $0.889 \mathrm{t}$ count $<\mathrm{t}$ table $(0.889<2.004)$, then reject $\mathrm{Ha}$ and accept Ho, meaning that partially Beta has no effect onEarnings Response Coefficient (ERC). The coefficient is negativethen Beta negatively correlated to the Earnings Response Coefficient (ERC).

Hypothesis three (H3) determines the effect of independent variables (independent vaiable) Growth opportunitiespartially on the dependent variable (dependent vaiable) Earnings Response Coefficient (ERC). Distribution table $\mathrm{t}$ at $\mathrm{a}=0.5$, the degrees of freedom (df) $60-4-1=$ 55, with a two-sided test (significance 0.05 ) was obtained t table of 2.004, based on table 4.5, $\mathrm{t}$ study of 2,224. $\mathrm{t}$ count $>\mathrm{t}$ table $(2,224>2,004)$, then accept $\mathrm{Ha}$ and reject Ho, meaning partial Growth opportunities significant effect on Earnings Response Coefficient (ERC).

Hypothesis four (H4) determines the effect of independent variables (independent vaiable) Firm Size partially on the dependent variable (dependent vaiable) Earnings Response Coefficient (ERC). Distribution table $\mathrm{t}$ at $\mathrm{a}=0.5$, the degrees of freedom (df) $60-4-1=55$, with a two-sided test (significance 0.05) was obtained t table of 2.004, based on table 4.5, $\mathrm{t}$ research at 2.887. $\mathrm{t}$ count $>\mathrm{t}$ table $(2.887>2.004)$, then accept $\mathrm{Ha}$ and reject Ho, that is partiallyFirm Size significant effect on the Earnings Response Coefficient(ERC). Hypothesis five (H5) to determine the effect of all independent variables consisting of Leverage, Beta, Growth opportunities and Firm Size together on the dependent variable (dependent variable) Earnings Response Coefficient(ERC).

By using a 95\% confidence level, a $=0.05$, df 1 (the number of variables -1$)=4$, df $2(n-k-1)=55(60-4-1)$, the obtained results $\mathrm{F}$ table 2,54. Meanwhile, based on the study table F 4 obtained by 4,172. F 
research $>\mathrm{F}$ table then accept $\mathrm{Ha}$ and reject Ho. That is to say Leverage, Beta, Growth opportunities and Firm Size simultaneously influence Earnings Response Coefficient (ERC). Based on the research, the regression equation on the hypothesis of a single during the observation period (2008-2012) display the test results by using variable Leverage $\left(\mathrm{X}_{1}\right)$ significant negative effect on Earnings Response Coefficient $(\mathrm{Y})$. The results of the $\mathrm{t}$ test showed $\mathrm{t}$ research greater than $\mathrm{t}$ table, it means accepting $\mathrm{Ha}$ and rejecting Ho. The coefficient is negative; thus it can be concluded that partial leverage proxied by the Debt to Asset Ratio (DAR) significant negative effect on Earnings Response Coefficient, this means that the higher the debt the company will be seen as a burden to be borne by the company.

Leverage the automotive companies that negativelythis is because the average long-term debt has decreased, while the assets of the company increased, so that the ratio of long-term debt to assets is getting smaller. This study supports the idea Dhaliwal et al. (1991) and Sri Mulyani (2003) that indicates earnings response coefficient negatively related to the level of leverage.

The test results using a Beta variable $\left(\mathrm{X}_{2}\right)$ showed no effect on Earnings Response Coefficient $(\mathrm{Y})$. The results of the $\mathrm{t}$ test showed t research less than $t$ table, it means to accept Ho and reject Ha. Beta has no effect on Earnings Response Coefficient (ERC), this proves that the investors in the automotive company does not see a risk factor as an obstacle to investing. This is evident in the development of sales are growing. By looking at these developments optimistic investors will get returns in the future. Based on the results of beta on automotive companies on average is still below 1 (one). This indicates that investment in automotive companies risk level is still small, so that investors do not have this concern. The results of this study are consistent with the results Chandarin (2003) supported by the results of research conducted by Harahap (2004), and Jaswadi (2004) which concludes that the systematic risk does not give effect to the ERC. 
The test results using variables growth opportunities $\left(\mathrm{X}_{3}\right)$ shows the effect onEarnings Response Coefficient $(\mathrm{Y})$. The results of the $\mathrm{t}$ test showed $\mathrm{t}$ research greater than $\mathrm{t}$ table, it means accepting $\mathrm{Ha}$ and rejecting Ho. The results show that the automotive company that has a great growth opportunity will have a high ERC. This condition indicates that the greater the opportunity to grow the company, the higher the chance of Companies gain or increase profits from the company in the future. In the automotive company is characterized by increased investment as indicated by the increase in places of assembly such companies across the region and the high increase in sales, this shows the growth of the company rose sharply.

Growth opportunities provided by the Price to Book Value Ratio (PBVR). The study finds consistentency with Collins and Kothari (1989), which shows that companies that have greater growth opportunities will have erning Response Coefficient (ERC) tall. The test results using variables Firm Size $\left(\mathrm{X}_{4}\right)$ shows the effect on Earnings Response Coefficient $(\mathrm{Y})$. The results of the $\mathrm{t}$ test showed $\mathrm{t}$ research greater than $\mathrm{t}$ table, it means accepting $\mathrm{Ha}$ and rejecting Ho. Result of this research shows that based on the company's growth large will be more likely to do the income smoothing practices than smaller companies, because large companies tend to get more attention from investors than small companies. Instead the company that has great assets which are then categorized as major companies in the automotive and components, for example Astra Int'l Tbk, and Indomobil in the automotive field and Goodyear Indonesia Tbk in the field of component generally will get more attention from various parties such as investors, and the government. Thus a large total assets reflects Earnings Response Coefficient Good, so the size of the company's influence on Earning Response Coefficient. This study proves that the size of the company is a significant explanatory variable for earnings response coefficient. 
Based on the research that has been done, from the regression equation on the hypothesis of five during the observation period (20082012) shows that the test results by using variable Leverage $\left(X_{1}\right)$, Beta $\left(\mathrm{X}_{2}\right)$, growth opportunities $\left(\mathrm{X}_{3}\right)$, Size $\left(\mathrm{X}_{4}\right)$. The results of the $\mathrm{t}$ test showed $\mathrm{t}$ research greater than $\mathrm{t}$ table, it means accepting $\mathrm{Ha}$ and rejecting Ho. That is to say Leverage, Beta, Growth opportunities and Firm Size simultaneously influence Earnings Response.

\section{Conclusion}

This study can be concluded as follows: leverage proxied by the Debt to Asset Ratio (DAR) significant negative effect on Earnings Response Coefficient; systematic risk (beta) had no effect on Earnings Response Coefficient (ERC); chance growth (growth opportunities) that proxied by Price to Book Value Ratio (PBVR) significant effect on Earnings Response Coefficient; size of company (Firm Size) significantly influence Earnings Response Coefficient; and the test results simultaneously by using all independent variables are Leverage, Beta, and Firm Size Growth opportunities showed positive and significant impact on the Earnings Response Coefficient (ERC).

\section{References}

Andayani, Nur F. F. dan Sri M. (2007). "Faktor-Faktor yang mempengaruhi Earnings Response Coefficient Pada Perusahaan yang Terdapat Di Bursa Efek Jakarta," Jurnal Akuntansi dan Keuangan. STIESIA Surabaya.

A. Zubaidi I. Agus Z. dan Ana R. (2011). Analisis Faktor-faktor yang mempengaruhi Earnings Response Coefficient (Studi pada perusahaan 
properti dan Real Estate yang terdaftar di BEI).

Cho, LY, and K. Jung. (1991). "Earnings Response Coefficients: A Synthesis of Theory and Empirical Evidence." Journal of Accounting Literature Vol.10. pp 85-116.

Claude et. all. (1996). "Political Risk, Economic Risk and Financial Risk", Financial Analysts Journal, November-December.

Departemen Keuangan RI, BAPEPEM. (2006). Keputsan Nomor: KEP134/BL/2006, tentang kewajiban penyampaian laporan keuangan tahunan bagi emiten atau perusahaan publik

Harahap, S. S. (2007). Analisis Kritis Atas Laporan Keuangan. Jakarta: PT. Raja Grafindo Persada.

Husnan, S. (2003). Dasar-Dasr Teori Portofolio dan Analisis Sekuritas Yogyakarta: BPFE Yogyakarta.

Husnan, Suad and Enny P. (2004). Dasar-dasar Manajemen Keuangan. Edisi keempat, YKPN : Yogyakarta.

Jogiyanto. (2009). Teori Portofolio dan Analisis Investasi. Yogyakarta : BPFE Yogyakarta.

Margaretta Jati Palupi (2003). Faktor-faktor yangmempengaruhi EarningResponse Coefficient pada perusahaan yang terdaftar di Bursa Efek Jakarta .Jurnal Akuntansi.

Minyue D and Qingmei X. (2010). The effect of governance transparency on earnings response coefficient: evidence from emerging markets.

Mulyani, S., Nur F.A. and Andayani. (2007). Faktor-faktor yang mempengaruhi Earnings Response Coefficient (ERC) pada perusahaan yang terdaftar di BEI. JAAI 1(1), pp. 35-45.

Murwaningsari, E. (2008). Beberapa faktor yang memepengaruhi Earnings Response Coefficient (ERC). Simposium Nasional Akuntansi (SNA) ke XI, Pontianak.

Moradi, M. S, Mahdi E. dan Zakiheh. (2010). A Study of Financial Leverage on ERC Throught Out Income Approach: Iranian Evidance. 
Naimah, Z. dan Sidharta U. (2006). Pengaruh ukuran perusahaan, pertumbuhan laba dan profitabilitas perusahaan terhadap Earnings Response Coefficient Dan koefisient respon nilai buku ekuitas. Simposium Nasional IX.

Pandji, A and Piji P. (2001). Pengantar Pasar Modal, Edisi Revisi, Rineka Cipta : Jakarta.

Riyanto, Bambang., (2001). Dasar-dasar Pembelanjaan Perusahaan, BPFE : Yogyakarta.

Suaryana. (2008). "Pengaruh konservatisme laba terhadap Earning Response Coeficient (ERC)," Naskah Publikasi Skripsi, Universitas Udayana.

Syafarudin, A.. (1994). Alat-alat Analisis dalam pembelanjaan, Andi Offset: Yogyakarta.

Van Horne, J. (2000). Financial Management and Policy, Prentice Hall : New Jersey.

Weston, J. Freed, and Scott Besley, and Eugene F. Brigham., (2001). Essential of Managerial Finance, The Dryden Press : New York. www. idx.co.id 


\section{Shirkah Author Guidelines}

Shirkah currently offers two routes to submit manuscripts. We highly recommend to submit the articles which are made using OJS (Open Journal System). Feel free register as author soon through visiting http:// shirkah.or.id/index.php/home/user/register. The authors may directly send their manuscripts, along with their resume, to shirkahiainsurakarta@ gmail.com. Please prepare your manuscripts, using following guidelines:

1. Manuscript must be written in English. Submitted articles should not have been published or be under review for publication with another journal.

2. Manuscript's length is about $15-20$ pages, typed in one-half spaced on A4-paper size.

3. Manuscript must include an $150-200$ word abstract and keywords.

4. Manuscript must be arranged as follows: Title, Name of Author, E-mail address, Abstract, Keywords, Introduction (including method if any), Discussion, Conclusion, References.

5. Manuscript's titles not more than ten words.

6. Manuscript must be submitted in Microsoft Word or RTF.

7. Arabic words should be transliterated according to the style of International Journal of Middle Eastern Studies.

8. Manuscript references are preferably derived from the up-to-date references.

9. The author's resume should be submitted separately, consisting of at least full name, institutional address, phone number, areas of studies, and recent publications (if any).

10. Shirkab use APA Style 6th edition (2010) as reference format writing. We suggest the use of a reference manager software such as Mendeley, Zotero, and Endnote at templating the citation style. APA Style to be used is as follows: 


\section{Book with single author}

Swann, G. M. Peter. (2014). The Economics of Innovation an Introduction. Cheltenhum \& Northampton: Edward Elgar.

in-text citation: (Swann, 2014)

\section{Articles in reference books}

Alatas, S. F. (2006). Islam and the Science of Economics in Abu Rabi', I.M. The Blackwell Companion to Contemporary Islamic Thought. USA: Willey-Blackwell (pp. 587-606).

in text citation: (Alatas, 2006)

\section{E-Book}

Hackett, Rosalind (2007). "Religous Dimentions of War and Peace: Introduction.” Dalam Gerrie ter Haar dan Yoshio Tsuruoka (Ed.), Religion and Society: An Agenda for the 21st Century (h. 3-6). Retrieved from http:// brill.nl.

in text citation: (Hackett, 2006)

\section{Master's thesis, from a commercial database}

McNieI, D. S. (2006). Meaning through narrative: A personal narrative discussing growing up with an alcoholic mother (Master's thesis). Available from ProQuest Dissertations and Theses database. (UMI No. 1434728)

in text citation: (Mc Niel, 2006)

\section{Doctoral dissertation, from an institutional database}

Adams, R. J. (1973). Building a foundation for evaluation of instruction in higher education and continuing education (Doctoral dissertation). Retrieved from http://www.ohiolink.edu/etd/

in text citation: (Adams, 1973) 


\section{Doctoral dissertation, from the web}

Bruckman, A. (1997). MOOSE Crossing: Construction, community, and learning in a networked virtual world for kids (Doctoral dissertation, Massachusetts Institute of Technology). Retrieved from http:/www-static. cc.gatech.edu/--asb/thesis/

in text citation: (Bruckman, 1997)

\section{Journal article with No DOI}

Bourkhis, K., and Nabi, M. S. (2013). Islamic and conventional banks' soundness during the 2007-2008 financial crisis. Journal Metrics, 22(2), 68-77.

in-text citation: (Bourkhis \& Nabi, 2013).

\section{Journal article with DOI}

Ichwan, M. (2012). The Local Politics Of Orthodoxy: The Majelis Ulama Indonesia in the Post-New Order Banten. Journal Of Indonesian Islam, 6(1), 166-194. doi:http://dx.doi.org/10.15642/JIIS.2012.6.1.166-194

In text citation : (Ichwan, 2012)

\section{Abstract as citation}

Hasan, N. (2012). Islamist Party, Electoral Politics And Da'wah Mobilization Among Youth : The Prosperous Justice Party (PKS) in Indonesia. Journal of Indonesian Islam, 6(1), 17-47. Abstract from http:// jiis.uinsby.ac.id/index.php/jiis/article/view/97

in text citation : (Hasan, 2012)

\section{Mass media article}

Sahal, Akhmad (2014, March 2). Kiai Sahal dan Realisme Fikih.Tempo Magazine, p. 120.

in text citation : (Sahal, 2014) 


\section{Research report}

Fisher, B. S., Cullen, F. T., \& Turner, M. G. (2000). The Sexual Victimization of College Women. Research Report.

in text citation : (Fisher, Cullen, Turner, 2000)

\section{Monograph}

Routray, Bibhu Prasad (2013), National Security Decision-Making in India (RSIS Monograph No. 27). Singapura: Rajaratnam School of International Studies.

in text citation : (Routray, 2013)

\section{Proceeding article}

Sudibyakto, Hizbaron, D.R., \& Jati, R (Ed.) (2009), Proceeding International Seminar Disaster Theory, Research and Policy. International seminar held by Sekolah Pascasarjana, Universitas Gajahmada, Yogyakarta, 8-9 Desember 2009.

in text citation : (sudibyakto and Jati, 2009)

\section{Paper conference/seminar/symposium}

Janutama, Herman Sinung (2011). "Kraton dan Hubungan Antar Agama." Paper presented in Seminar Kraton dan Panatagama held by Center for the Study of Islam and Social Transformation (CISForm), Yogyakarta, 17 November.

in text citation :(Janutama, 2011)

\section{Online article in web}

Shiva, (2006, February). Bioethics: A Third World Issue. Native-web. Diperoleh dari http://www.nativeweb.org/ pages/legal/shiva.html

in text citation : (Shiva, 2006) 


\section{Online research report}

Kessy, S. S. A., \& Urio, F M. (2006). The contribution of microfinance institutions to poverty reduction in Tanzania (Research Report No. 06.3). Retrieved from Research on Poverty Alleviation website: http://www. repoa.or.tz /documents_storage/Publications/Reports/06.3_Kessy_and_ Urio.pcif

in text citation : (kessy and urion, 2006)

\section{Holy book}

Qur an, $2(25)$

In text citation : (Q. al-Baqarah 2:25).

\section{Encyclopaedia}

Graycar, Adam (1992). Social Welfare Policy. Dalam Mary Hawkesworth dan Maurice Kogan (Ed.), Encyclopedia of Government and Politics (Vol. 1). London: Routledge.

in text citation : (Graycar, 1992)

\section{Interview}

Sultan Hamengkubuwono X (interview, 2011, April 19)

in text citation: (Hamengkubuwono, 2011)

\section{Documentary film}

Steijlen, Fridus (2008). A Day in the Life of Indonesia [documentary film, 58 minutes]. Leiden: KITLV Press.

in text citation : (Steijlen, 2008) 
Vol. 2 No. 2, May - August 2017 